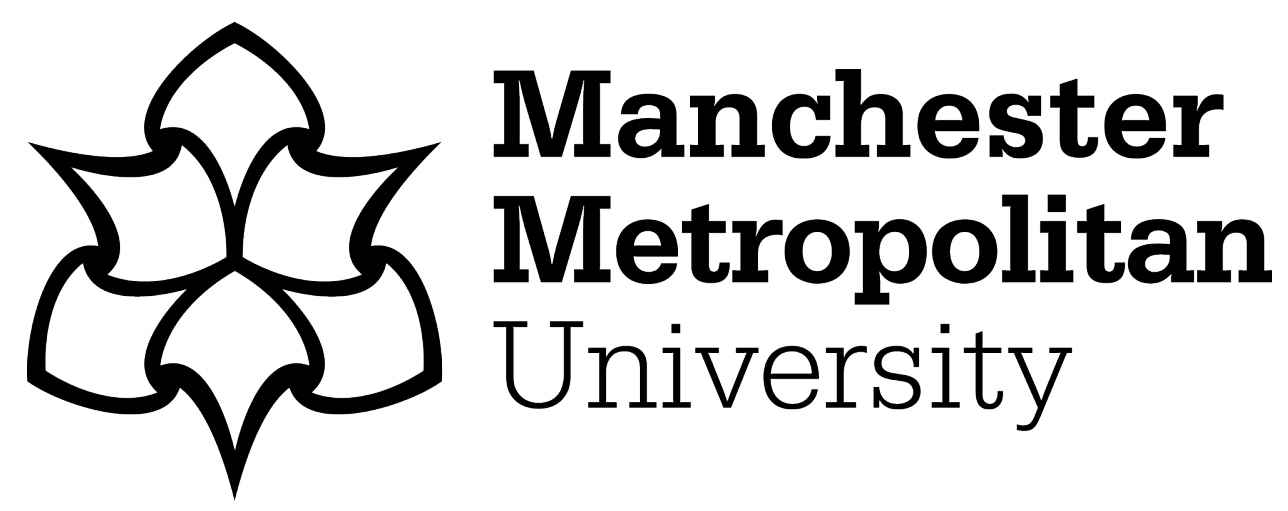

Antoniadou, Marilena ORCID logoORCID: https://orcid.org/0000-0002-4025035X, Crowder, Mark and Stewart, Jim (2019) Exploring Perceptions of Academic Management Roles in the Undergraduate Student Experience. Student Engagement in Higher Education Journal, 2 (2). pp. 61-78.

Downloaded from: https://e-space.mmu.ac.uk/622759/

Version: Published Version

Publisher: University of Greenwich

Usage rights: Creative Commons: Attribution 3.0

Please cite the published version 


\title{
Exploring perceptions of academic management roles in the undergraduate student experience
}

\author{
Marilena Antoniadou, Manchester Metropolitan University, \\ m.antoniadou@mmu.ac.uk
}

Mark Crowder, Manchester Metropolitan University, m.crowder@mmu.ac.uk Jim Stewart, Liverpool John Moore University, j.d.stewart@ljmu.ac.uk

\begin{abstract}
This article explores key roles and responsibilities undertaken by academics working in the UK higher education in relation to the student experience. Based on a case study of a large, modern university, we explore perceptions of three management roles that academics perform alongside their academic duties; namely programme leader, year tutor and personal tutor. Drawing on Brookfield's (1995) four-lens framework, these roles are examined from multiple actors' perspectives: students, peers, educational researchers, and autobiographical experiences. This study makes an important theoretical contribution by applying Brookfield's four-lens framework not previously used in researching academic life, whilst empirically it offers insights into how each management role is enacted, and related to various aspects of the student experience. These unique theoretical and empirical insights have implications for enhancing the student experience and support academics into the enactment of management roles.
\end{abstract}

\section{Introduction}

Higher Education (HE) has experienced substantial change in recent decades. The marketisation of universities (Wilmott, 1995; Palfreyman \& Tapper, 2014), increasing student numbers, and a new tuition fee regime in England, have placed the undergraduate student experience firmly on university agendas (Buultjens \& Robinson, 2011), with regulatory bodies emphasising the need for effective student support systems, 'particularly in the context of rapid expansion (HEQC, 1996, p. 46). This move towards massification, which is not unique to UK HE, has consequences for management roles undertaken by academic staff members in a need to enhance student support (Vilkinas \& Ladyshewsky, 2012). Such roles include the introduction of year tutor ${ }^{1}$ for large programmes, whilst existing roles, such as the one of programme leader and personal tutor, have imposed changes (Willmot \& Lloyd, 2005). Although, the roles of the programme leader and of academic directors (e.g. Milburn, 2010; Mitchell, 2015) and the importance of personal tutors has been well-documented in the HE literature (e.g. Wheeler \& Birtle, 1993; Hartwell \& Farbrother, 2006), the problematic time pressures involved in monitoring and supporting large number of students created the need for year tutors in some universities, who are

\footnotetext{
${ }^{1}$ We are using the term Year Tutor for this paper. We recognise similar roles may have a different title, such as 'Head of Year', 'Year Head',

'Departmental Head'.
} 
becoming involved in helping students confront the various difficulties they face (Willmot \& Lloyd, 2005). These three roles appear as strategic to the university, especially in times of rapid change, as they play a key role in not just the delivery of teaching programmes, but also to student support, student employability and in linking the faculty/department and the instructional staff to students (Milburn, 2010; Vilkinas \& Ladyshewsky, 2012). However, these roles are not yet recognised as separate within the $\mathrm{HE}$ literature, with the emerging role of the year tutor being completely absent.

Predicated on growing evidence that students have higher levels of engagement and learning at institutions where academics interact with them, support them, and challenge them intellectually (Wilcox, Winn \& Fyvie-Gauld, 2005; Palmer, O'Kane \& Owens, 2009; Bowden, 2013), this article aims to strengthen the focus on the people who lead or are directly involved in the experience of undergraduate students. An original contribution of this article is that, for the first time, it explores the relationship between academic management roles, such as year tutors, personal tutors and programme leaders, and their relationship with the various aspects of the undergraduate student experience. To achieve a spherical exploration of these roles, Brookfield's (1995) four-lens model was applied to provide clarity and information to the HE sector on these important roles of academic staff members. This has clear implications for educational theory because it shows that the model can be used in a wider range of contexts than hitherto thought. Instead of aiding reflection on academics' performance (the 'how' or 'how well'), the model has been used to identify the processes involved in these roles (the 'what'). This brings a level of objectivity to what could otherwise have been an exclusively subjective study. Adopting Brookfield's work as the conceptual framework excludes application of a more precise theory in analysis of the phenomena being examined. However, we are currently undertaking additional work utilising role theory where concepts of expectations, identity and role conflict have been applied, especially in educational research and settings (Biddle, 2013). Role theory will be more relevant to future micro analyses of the experience of those undertaking the various roles described here.

The next sections review the theoretical framework related to the student experience in $\mathrm{HE}$, which leads into an exploration of the three management roles that academics commonly undertake. These sections provide a synopsis of the educational literature (one of Brookfield's 1995 lenses), hence part of the study's conceptual framework.

\section{Conceptualising the student experience}

The student experience is key to determining how good a university is perceived to be, with clear links to quality and value for money as key indicators (Staddon \& Standish, 2012). Understanding the student experience is critical for universities in managing the transition from school to tertiary study, in retaining students, and in preparing the foundations for academic success (Krause, 2005). There is a broad consensus in the literature about what the student experience entails, with its components covering the entire student lifecycle, from pre-entry to graduation (Table 1). The student experience is a continuous 
and developmental process during which students mature intellectually, personally, emotionally, and ethically (Perry, 1970).

Table 1: Student experience components based on Temple et al. (2014)

\begin{tabular}{|l|l|}
\hline \multicolumn{1}{|c|}{ Components } & \multicolumn{1}{|c|}{ Source } \\
\hline $\begin{array}{l}\text { The pre-entry experience - interactions between } \\
\text { potential students and the university, up to the point } \\
\text { of arrival }\end{array}$ & Ramsden (2008) \\
\hline $\begin{array}{l}\text { The academic experience - student interactions } \\
\text { with the university, including academic support, } \\
\text { teaching and learning. }\end{array}$ & $\begin{array}{l}\text { 1994 Group (2007); } \\
\text { Benckendorff et al. (2009); } \\
\text { Buultjens \& Robinson (2011) }\end{array}$ \\
\hline $\begin{array}{l}\text { The campus experience - student life not directly } \\
\text { connected with study, including activities away from } \\
\text { the campus. }\end{array}$ & 1994 Group (2007) \\
\hline $\begin{array}{l}\text { The graduate experience - the institution's role in } \\
\text { aiding students' transition to employment. }\end{array}$ & $\begin{array}{l}\text { 1994 Group (2007); } \\
\text { Buultjens \& Robinson (2011) }\end{array}$ \\
\hline
\end{tabular}

Social networks, such as students' peers and tutors, have immense importance in the academic lives of students (Wilcox et al., 2005); where this is lacking, withdrawal is common, particularly in the first year (Willcoxson, Cotter \& Joy, 2011) due to difficulty in coping with the transition to university, lack of support, financial pressures, and unfulfilled expectations (Nelson, Kift \& Clarke, 2012). Indeed, the first-year experience can be daunting and lonely, with students lacking social networks, which exacerbates their sense of helplessness (Bowden, 2013). Later in their studies, students encounter different, but equally significant, pressures. For instance, final-year students focus upon employability, which encourages them to seek extra-curricular options to develop their skills. This has a clear impact on graduate employability, leadership and communication, and self-promotion skills (Thompson, Clark, Walker \& Whyatt, 2013). Thus, a key challenge for universities is not simply the provision of high quality academic content but also positive tutor-student interaction (Bowden, 2013) which is facilitated by personal tutors, year tutors, and programme leaders.

\section{Personal tutor}

The personal tutor (PT) mainly has a pastoral role and acts as a mentor, who facilitates the personal development of their tutees, monitors progress and provides a link between the student and the university for the student's entire educational journey (Wheeler \& Birtle, 1993; Thomas, 2006). The role is usually non-teaching, and involves helping students with personal problems (Kilduff, 2014), offering academic support (Newton \& Smith, 1998) and helping them to navigate organisational procedures (Robertson, 2014). Mutual trust, engagement and respect are important elements of the PT-student relationship (Dobinson-Harrington, 2006), with PTs expected to be friendly and approachable, be willing to continue the relationship outside the classroom, and be good role models (Quinn, 2000). 
Year tutor

Although the PT role has gained attention in the literature, there is a paucity of research into the year tutor (YT) role. This has been defined loosely as having responsibility for one year of a course (Tait, 1998), or even more vaguely as 'just doing my bit' (Newton, 2002, p. 124). The role is administrative and pastoral, entailing activities such as guidance and counselling (Tait, 1998) or, more generally, sorting out students' personal and academic problems (Atkinson, 2014). Unavoidably, there is some overlap between YTs and PTs. Indeed, one definition of the $\mathrm{YT}$ is someone who 'fulfils the personal tutor role for all students at that level' (Owen, 2002, p. 13), although Vinson et al. (2010) argue that YTs have minimal contact with students due to the role's administrative nature.

Few British universities have YT job descriptions. For example, the role usually forms a small part of a wider job description for lecturers or senior lecturers (e.g. Lancaster University 2015). Descriptions of the role are typically very sparse, and range from substantial responsibility for the student experience (Coventry University 2015), to being a 'senior administrative role' (Lancaster University 2015). In most cases, prior experience of year tutoring is not a requirement for the role.

\section{Programme leader}

The programme leader (PL), another under-researched role (Murphy \& Curtis, 2013), is responsible for the quality and administration of a course (Paterson, 1999), but can also be involved in activities such as teaching, student profiling, quality assurance, managing enrolment and retention, and liaising with external stakeholders (Vilkinas \& Ladyshewsky, 2012). The role has a strong managerial component (Mitchell 2015), where traditional line-management responsibility is replaced by coordination (Milburn 2010). However, PLs are more than caretakers of a particular course and can also contribute to long-term change and vision (Knight \&\& Trowler, 2001). PLs have partial autonomy, and although administrative and managerial responsibilities are central, the need for leadership is also vital (Mitchell, 2015).

\section{Conceptual framework}

To assist the exploration of academics' perceptions of their management duties and examine how each role may be linked to aspects of the undergraduate student experience, we draw upon two frameworks: Brookfield's four lenses (1995) and Temple, Callender, Grove Kersh's (2014) framework of the student experience. We employed these frameworks to explore what each aspect of the above management roles does in relation to the four aspects of the student experience (Table 1) and to provide clearer descriptions of these roles.

Brookfield's (1995) four-lens model was originally developed as a tool to help teachers to reflect on their own performances, and consists of four perspectives through which a situation can be viewed: teacher's own lens, students' lens, peers/colleagues' lens, and literature lens. It also relates to the study's overarching phenomenological approach, which argues that there is rarely a single correct answer: rather, a subjective reality is constructed between the researcher and participants. There is a long pedigree of Brookfield's (1995) four- 
lenses being used for reflection in teaching and learning contexts (e.g. Faulkner \& Crowhurst, 2015; Ndebele, 2014). However, the present study is different, because it does not reflect on the effectiveness of the performance of the roles; instead, the focus is on establishing what the roles of personal tutor, year tutor and course leader are as practised.

The second framework underpinning this study is Temple et al.'s (2014) conceptualisation of the elements of the student experience. According to Temple et al. (2014) these elements are summarised in four chronological periods along the student journey. These four elements include: a) the pre-entry experience, covering interactions between potential students and the university, up to the point of arrival, b) the academic experience, including student interactions with the university, including academic support, teaching and learning, c) the campus experience, including student life not directly connected with study, including activities away from the campus, and d) the graduate experience, covering the institution's role in aiding students' transition to employment. This framework is particularly significant because it does not focus solely upon teaching and learning activities. It recognises that factors such as social life, academic administration and extra-curricular activities also affect the student experience.

There is a paucity of literature about how each management role is enacted, and related to these four elements of the student experience. This study addressed the following aims: (i) to identify how the roles of programme leader, year tutor and personal tutor differ, and (ii) to explore how each role influences the undergraduate student experience.

\section{Methods}

The capture the perceptions of participants in a way that prioritises their own interpretations of a role, a phenomenological approach was used (Moustakas, 1994). In this study's case, the authors needed to discover the meaning of the role of personal tutor, year tutor and programme leader. To achieve this, human behaviour must be experienced first-hand, and qualitative methods are the most appropriate approach for a detailed description of the investigated area and a rich insight into participants' experiences (Sanders, 1982).

Phenomenologists are necessarily implicated in the process, since only in this way can the understanding of the participants' psychological world be achieved (Frank, 1997). As such, our research reflected on our own practice in relation to the examined phenomena, as individuals who have undertaken these roles or who have worked with people who performed these roles. In alignment with Brookfield's model, reflective considerations were integrated as part of the data collection and analysis.

\section{Participants}

This study was conducted within a large UK university, which embeds all three management roles in its undergraduate programmes. The number of participants was defined during, not at the start, of the study because the guiding principle was theoretical saturation - the point at which researchers no 
longer see new categories, concepts or dimensions appearing in the data (Strauss \& Corbin, 1998). Eight students, five first-years and three final-year ones, represented Brookfield's 'students' lens'. Fifteen peers, four being Programme Leaders, four being first-year year tutors, five being final-year year tutors, and two personal tutors, represented the 'peer lens' (Table 2). The authors' reflective accounts represented the 'reflective lens'.

\section{Procedure}

The core of the research was a series of semi-structured interviews. Participants were asked open questions, which were followed by additional probing questions that allowed the researchers to explore the emerging topics in more detail. Each interview lasted between forty and sixty minutes, and notes were taken manually and written up in Microsoft Word immediately after the interviews. All participants were offered the chance to read the electronic interview notes to check for correctness, and to allow them to add or remove information as they wished.

Thematic analysis and reflective writing were used to analyse the interview data. Each participant viewed the roles from the lens of their own values, expectations, and experience, whilst the researchers came to the study based on their background and experiences from undertaking some of the roles. Hence, participants and researchers developed a shared understanding of the phenomenon. During the analysis, themes emerged from the data, uncovering essences that make the nature of the phenomenon what it is. Reflection facilitated recognition of how each phenomenon was experienced in the researchers' own life-worlds (Frank, 1997).

Table 2: Participants' Profile

\begin{tabular}{|c|c|c|}
\hline Participant & $\begin{array}{c}\text { Years in current } \\
\text { role }\end{array}$ & Position \\
\hline Christine & 4 & Year tutor - Year 1 \\
\hline Jane & 4 & Year tutor - Year 1 \\
\hline Clarisa & 1 & Year tutor - Year 1 \\
\hline Kate & 2 & Year tutor - Year 1 \\
\hline Andy & 10 & Year tutor - Final Year \\
\hline Kim & 2 & Year tutor - Final Year \\
\hline Peter & 2 & Personal tutor \\
\hline Filipa & 1 & Personal tutor \\
\hline Stephan & 2 & Year tutor - Final Year \\
\hline Annabel & 3 & Year tutor - Final Year \\
\hline Samantha & 1 & Year tutor - Final Year \\
\hline Daniel & 4 & Programme Leader \\
\hline Karina & 4 & Programme Leader \\
\hline Scott & 3 & Programme Leader \\
\hline Juliette & 2 & Programme Leader \\
\hline & & \\
\hline
\end{tabular}




\begin{tabular}{|c|c|}
\hline Fabio & Year 1 student \\
\hline Sabina & Year 1 student \\
\hline Arnold & Year 1 student \\
\hline Leah & Year 1 student \\
\hline Anderson & Year 1 student \\
\hline Saeed & Year 3 student \\
\hline Steven & Year 3 student \\
\hline
\end{tabular}

\section{Findings}

Consistent with Brookfield's (1995) model, we report perceptions of the three roles that emerged in participants' own words as (i) students' lens, (ii) colleagues' lens (iii) reflections' lens. The literature lens has been discussed above. Then, we reinterpret the findings using Temple et al.'s framework of student experience.

\section{The student lens}

It was evident from the interviews that all students knew who their YTs were, although not everyone knew the names of their PTs or PLs. Students of all levels felt that the YT is responsible for the welfare of their academic studies. In particular, first-year students regarded pastoral support and guidance as key duties of YTs, because entering university was a big change in their lives, and it was essential to have someone to help them adapt to this new environment. Fabiano, an international first-year student, admitted initially feeling scared of going to lectures, but having someone who not only teaches him but also bonds with him on a personal level made his student experience more enjoyable. Also important was support to aid understanding of university requirements and processes, and associated opportunities. For example, Sabina, a first-year student, referred to her decision to change her mode of study to a placement course, which would allow her to spend a year in industry:

I see my YT as a person who help us go through the academic year that we have a bond with. I only found out from my YT about the placement year - I wouldn't have known otherwise. I switched and work closely with my PT to find a placement.

For Sabina, although communication flow came from her YT, a close relationship to secure a placement was made by her PT. For all students, transition, induction and employability were key elements of all three roles. Another first-year student characterised his YT as a 'senior teacher responsible for our year' and 'someone to rely on and help us grow academically'. Some students expected their YTs to provide information about the university, and others wished to be encouraged to attend extra-curricular events in order to enhance their personal and employability skills. Saeed's comment was typical:

My YT informs us about extra activities, such as employability, societies and postgraduate fairs. I know this is available anyway, but it's another way to get the message out there, and sometimes that's all it takes. 
There was strong agreement from all students that YTs and PTs are and should be directly involved in teaching them. Saeed's rationale for this was that if they are also their lecturers 'they understand the programme and they are in a better position to advise than they would be if they were more distant'. Students viewed the PT role as more pastoral because it focuses upon personal issues on a one-to-one basis, whereas YTs have an oversight role. As Arnold, a finalyear student put it:

My PT is my guide and advisor. From my PT I want a friendly and approachable personality, a personality that says "you can come and talk to me".

Given that students were not routinely exposed to the responsibilities of the PL, it is perhaps unsurprising that some were completely unaware of what the PL role does.

The peers' lens

Peers included participants who performed at least one of the three roles. All current YTs felt that YTs and PTs should be academics and not administrative support staff, because academics can understand the impact of their interventions on the student experience and the implications for progression on the units and wider programme. Again, the YT role was difficult to define.

Annabel, a final-year YT, stated that 'I'm scared to ask! If I go to my manager and ask what the role is, I might find out that l've been doing it all wrong!' Andy, who currently performs the YT role, emphasises the lack of clarify and the reactive nature of the role:

I had no prior experience. I didn't know what the role was, so I tried to find out. Management said that it was about managing the overall programme at arm's length. All I had to do was to show up and deal with anything that arose. It was all very abstract...going to board meetings and keeping an eye on how things were going. All I found out were fragments...I never saw the big picture. I never knew how it all fitted together. I just waited for emails. Emails didn't arrive unless there was a problem.

Other peers were concerned by the lack of guidelines and absence of a job description, and many who performed both roles indicated that the role clashed with their PT duties. Stephen resolved this ambiguity by simply ignoring it:

I'm a PT and a YT. Are they different? I suppose they must be...There's an issue with how these roles are delineated and where the responsibility lies. I tend to ignore the differences. If a student asks me something, I'll try to answer it. I don't send them away because something is not my role...It's common sense.

Daniel, an experienced PL, commented that the $\mathrm{YT}$ is 'a role that is used to fill gaps in people's workload', and noted that YTs 'are not recruited for, but are assigned'. All peers argued that YTs act as the contact point for academic issues such as electives, regulations and policies. Kate who has been a YT for two years:

It's a mixture of disciplinary issues, preparing and delivering induction, chasing non-attendance, attending examination boards, writing references, 
attending staff-student liaison meetings, recruiting student reps...Extracurricular activities are coordinated and planned via the student society and we promote them. I also deal with the general results for progression of all L4 students.

Current PTs also felt that their role included pastoral and managerial duties, such as assisting progress and dealing with personal issues, and emphasised the administrative workload the role involves. Samantha, who had experience in both personal and year tutorship, described it thus:

Both are management functions...As a PT, I am a glorified post box. A query comes to me, I forward it on to programme support for an answer, they reply to me, I reply to the student. A YT admin-based. You organise induction - it's you that has to stand up and talk to everyone through the basics. You have to go to open days and programme boards too.

Whilst recognising the overlap between PT and YT roles, Annabel noticed that the type of support differs. Whilst 'a PT helps with moral support and motivation, a YT looks after timetables, lack of consistency between tutors and between units and looks closer to a programme management role'. Similarly, other peers agreed that YTs and PLs have overlapping responsibilities, but recognised that the roles are not identical. Andy noted that:

The YT role is mostly ad hoc. The PL role sets the procedures to be followed. The YT role is a sweeper-up role, not strictly a procedural one.

Katy, a PL, claimed that because YTs are unaware of what to do because they have not been properly recruited and trained, she is effectively doing the role for them:

YTs should be doing induction, but I end up doing it. The PL is about sorting out strategic issues. Dealing with recruitment, figures, organising open days, gets the programme team together, sees what progression is like, and tries to get the students to a better level.

Current PLs regarded this lack of clarity because of the changing nature of HE. The PT role was developed to provide a one-to-one relationship between the student and the lecturer, whereas the YT has a coordinating role. Nevertheless, many peers from all roles argued that although the PT should be the first point of call for non-academic issues, the expanding nature of the YT role, and the engagement that many YTs display, means that this role is more visible to the students. It has also made the role more personal.

\section{Reflection lens}

In line with Brookfield's third lens, two of the authors reflected upon at their own experiences as YTs and PTs, and of working with PLs. None of the authors received a job description, and have essentially developed the roles themselves 'on the job'. Author A felt that being a YT is about 'acting as the contact point for all students in the year for advice, support and general guidance on academic and non-academic issues, and guiding them to appropriate support'. In the first year, 'the overall aim is improving student retention', whereas Author B's comment is that in the final year the main aim 'is enhancing student 
employability'. Designing and delivering induction, dealing with timetabling queries, and coordinating the PTs were commonly experienced in the YT role by the authors.

All authors agreed that the PL role is administrative, managerial and strategic. It involves embedding Programme Learning Outcomes within units, ensuring that the programme meets accreditation bodies' requirements, working with stakeholders, reporting to senior management, reviewing and implementing quality assurance, and liaising with external examiners.

As with other participants, the authors identified overlaps between YT and PT roles:

YTs take a programme-based view, and are involved at a strategic level, planning and designing parts of the programme. They meet with unit leaders to ensure that units have a broadly consistent approach across the year. High student numbers preclude a close relationship with most students. This is one reason why PTs are needed - to ensure that all students are helped and that nobody slips through the cracks. (Author A)

PTs take a student-based view. They focus on the needs of their specific cohort. PTs get to know each of their students personally and build up a relationship with them. PTs can be involved in providing academic help, but often find themselves helping in a pastoral way. (Author B)

Author $\mathrm{C}$, despite not having experience of the role of PT or YT, had extensive experience as a PL. Author C's reflection was that lack of clarity among staff and students, especially confusion arising from overlapping responsibilities, are from the PL perspective a weakness of such student support structures. PLs generally have overall responsibility and accountability for the success of programmes, and, as noted above, the level and quality of support provided by PTs and YTs has an impact on student experience. Author $C$ therefore felt that it is in the interests of PLs that PTs and YTs operate effectively, and this requires complementarity rather than confusion in those roles. Achieving effectiveness among PTs and YTs will, for a PL, be a major contributor to programme level success. The roles are also potentially valuable in easing the workload and burden of PLs in ensuring student satisfaction.

\section{Discussion}

This study sought to explore the roles of programme leader, year tutor and personal tutor and examine how each role impacts on aspects of the undergraduate student experience. The findings have revealed practices from the three roles and have identified how each role deals with multiple tasks related to the student experience as per Temple et al. (2014), as depicted in Figure 1. Notably, the three roles tended to converge on numerous tasks. One factor influencing this overlap was the lack of clear role descriptions and the absence of formal recruitment processes for the year and personal tutors. It was also clear that the roles covered a range of aspects that are embedded throughout the student experience, from pre-entry contact through to graduation and beyond. 


\section{The pre-entry experience}

One of the most important duties that all lenses mentioned was

transition/induction, both in terms of entering university for the first time, but also in terms of transition between years. This study found that PLs are responsible for the pre-entry experience, via open days and school visits, which help to shape prospective students' expectations (Hill, 1995). First year YTs facilitate student integration into Higher Education (HE) and link the student directly into the university, and PTs are responsible for the dissemination of academic expectations. This combination of duties is particularly important for first-year students, who confirmed the student-tutor relationship as being crucial (e.g. Krause \& Coates, 2008; Palmer, 2006). This also has implications for completion rates (Wilcox et al., 2005), since some students feel trepidation about entering HE (Thomas, 2006). Several students expressed similar views and argued that their YTs and PTs facilitated this transition.

Students entering HE come from varying backgrounds (McCaig, 2016) and may experience family or social pressures to perform well, and this can lead to anxiety or stress (Wheeler \& Birtle, 1993). Family responsibilities and financial hardship can add to the burden (Grant, 2006). Many students of the study expected YTs to lessen this pressure and deal with potential and actual academic failure, whereas all students expected PTs to offer one-to-one support and guidance on pastoral and academic performance; something that the literature again supports (Douglas, Douglas, McClelland \& Davies, 2015; Grant, 2006).

\section{The academic experience}

The findings support previous research (Owen, 2002; Atkinson, 2014) that the PT role is pastoral, whereas the PL and YT roles are more mixed. Participants from all lenses viewed the provision of pastoral and academic help as being a crucial part of the YT role (Earwalker, 1992), with students expecting them to provide information on examinations and university regulations and to build relationships with them as individuals. This view reflected PT comments, which strongly argued for the need to offer help and guidance, and act as the first point of contact for student problems, in order to develop social and academic relationships with the students. Moreover, all participants felt it was essential for PTs and YTs to understand the curriculum and the units taken by their students in order to provide informational support (Wilcox et al., 2005).

\section{The campus experience}

Several duties and responsibilities of all roles were not directly connected with academic matters, but included activities away from the campus. Students noted that they are encouraged to attend out-of-class events to improve their personal and employability skills (Thompson et al., 2013), and that YTs and PTs play an integral part in this; something that also emerged from the authors' reflections. Indeed, extracurricular activities can lead to a range of desirable outcomes such as critical thinking and organisational skills, and this has implications for students' academic, social and intellectual performance (Terenzini, Pascarella, 
\& Blimling, 1996). Examples of this from the study include the involvement of all parties in activities such as organising social events.

\section{Employability/graduate experience}

Employability emerged strongly as a key theme in each role. The literature is largely silent on this point and, in general, does not consider the involvement of YTs or PTs in enhancing employability (Kilduff, 2014; Thomas, 2006). Notable exceptions are Hartwell and Farbrother (2006), who argue strongly for an enhanced personal tutor system to strengthen employability beyond formal academic tutoring. The authors' own reflections highlighted several elements related to planning and promotion that directly help students with their personal, employability and educational development. Examples were the formation of a programme society, writing references and advising on student employability and postgraduate studies.

\section{Implications for theory and practice}

This study has important implications for theory and for management practice within HE. The study has, for the first time, identified the duties of three academic management-based roles from multiple perspectives, and the relative importance of different functions varying according to each perspective.

Students value soft skills such as empathy, listening, whilst managers value hard skills such as organisational ability, and academics themselves stressed the high volume of administrative work. Whilst there does not seem to be a universal acceptance that satisfies all parties, having identified the key duties, it would be possible to use these to develop an appropriate role description. This is significant because even though PT and YT roles do not normally represent a full-time-equivalent post, the duties form a significant percentage of the responsibility of the current incumbents. Hence, a role description will not only bring much-needed clarity to the role allowing to also develop formal performance measures, but students would also have a greater understanding of what their tutors can and cannot do to help them.

Finally, a formal role description could significantly aid the recruitment process. As several participants observed, PTs and YTs are not currently recruited based on their suitability or experience - something of an anomaly given the evident importance of the roles. This could be addressed if duties were formalised. So too could support in the form of training for those newly recruited to the roles. Additional forms of development such as mentoring schemes would also be aided by the use of job descriptions.

The study findings are also significant in helping management to understand the roles, and the importance of affective bonds, from the student perspective. It also helps management to understand faculty perceptions of the importance of creating a sense of belonging and inclusiveness for students. In an era when universities are conceptualised as service providers and are challenged by 'the customer is always right' effects (Constanti \& Gibbs, 2004), academics are in danger of becoming impersonal. Hence, the need to provide an outstanding student experience is more urgent and more challenging, than ever. This study has shown that academics are involved at every stage of the student journey, 
which means that they can have a significant impact upon the student experience.

Another important implication for management is that this study has identified several overlaps between the different roles. Duplication of workload is clearly inefficient, and addressing this will allow managers to free up staff time to focus on other priorities. In addition, there is some evidence that different roles are providing conflicting advice. This affects students, who are unsure which version is correct, but there is also an impact on staff morale - 'why should I bother when I am only going to be contradicted by someone else'? There are, therefore, clear organisational benefits to bringing greater clarity to all involved.

A significant contribution to theory from this study relates to Brookfield's (1995) four-lens model. The model is usually used as a tool to help teachers to reflect on their own performance (Faulkner \& Crowhurst, 2015; Ndebele, 2014) and this study represents the first time it has been used in the present context. The model has allowed situations to be explored from a range of viewpoints, and this provided a richer data set than might otherwise have been the case (Samah, 2013). It was simple to use, and easy for participants to understand. On the basis of this study, we argue that the model is relevant for future research, perhaps in new contexts, because of its flexibility, and its ability to triangulate observational and interview data and integrate this with the literature.

\section{Conclusions}

This paper considered some of the management roles undertaken by academics, namely, personal tutor, year tutor, and programme leader, and has related these to the student experience. There is considerable overlap between the roles, and this is exacerbated by a lack of formal guidance and lack of meaningful job descriptions. Consequently, academics take elements from their own experiences to develop the role rather than following a prescribed set of instructions. There is, therefore, a need to clarify the different roles - not least because this study has shown that each of these roles impacts directly on the entire student experience.

Given the importance of the three roles, it is worrying that recruitment processes are often flawed. Previous experience in these roles is rarely considered by senior management, and roles are merely assigned - sometimes on a rather flimsy basis such as free space in a workload model rather than suitability for the job. Hence, this paper has practical implications for HR professionals and senior managers who can make informed decisions on the basis of evidence.

Future research could fruitfully investigate the potential generalisability of this study's findings by studying academics' management roles in other institutions and/or in other countries. This might also include an exploration of the roles in a postgraduate context, since there may be some important differences due to smaller numbers and greater independence of students at this level. This would potentially provide a useful counterpoint to the present study and would further illuminate a hitherto grey area within the educational literature. This paper has begun the process of unlocking a new field of research, and the authors will be 
contributing to this through further work utilising role theory in analysing our data. It will be interesting to see how this develops in the coming years.

Student Engagement in Higher Education Journal

Vol 2, Issue 2, January 2019 
Figure 1: Synthesis of the three roles in relation to the student experience, based on the four lenses

\begin{tabular}{|c|c|c|}
\hline \multicolumn{3}{|c|}{ PRE-ENTRY EXPERIENCE } \\
\hline PROGRAMME LEADER & YEAR TUTOR & PERSONAL TUTOR \\
\hline $\begin{array}{l}\text { - Promote programme and recruit students } \\
\text { - Open/Visit day planning } \\
\text { - Review applications } \\
\text { - Conduct interviews }\end{array}$ & $\begin{array}{l}\text { - Assist transition from school to university } \\
\text { - Open/Visit day participation } \\
\text { - Design and lead induction } \\
\text { - Develop relationships with students and parents }\end{array}$ & • Induction involvement \\
\hline \multicolumn{3}{|c|}{ ACADEMIC EXPERIENCE } \\
\hline PROGRAMME LEADER & YEAR TUTOR & PERSONAL TUTOR \\
\hline $\begin{array}{l}\text { - Design and develop programme } \\
\text { - Continuous programme monitoring and } \\
\text { improvement } \\
\text { - Manage academic appeals, disciplinary process } \\
\text { - Co-ordinate teaching staff } \\
\text { - Programme quality } \\
\text { - Share information and facilitate communication } \\
\text { - Forecast retention and withdrawal rates } \\
\text { - General management (timetabling, programme } \\
\text { specifications, suspensions, extensions, etc.) }\end{array}$ & $\begin{array}{l}\text { - Day-to-day responsibility for a designated cohort } \\
\text { - Liaison with unit leaders about teaching } \\
\text { - Teach core units for their designated year } \\
\text { - Lead staff-student liaison meetings } \\
\text { - Student timetable changes } \\
\text { - Recruit student representatives } \\
\text { - Assist students to make choices about electives } \\
\text { - Monitor attendance and progress } \\
\text { - Liaise with personal tutors over performance and } \\
\text { - disciplinary issues } \\
\text { - Participate in exam boards }\end{array}$ & $\begin{array}{l}\text { - Monitor progress } \\
\text { - Help with study skills } \\
\text { - Help with writing essays and exam techniques } \\
\text { - Support with issues related to learning need } \\
\text { - Supervise projects and dissertations } \\
\text { - Communicate with year tutors in relation to } \\
\text { students experiencing difficulties. }\end{array}$ \\
\hline \multicolumn{3}{|c|}{ CAMPUS EXPERIENCE } \\
\hline PROGRAMME LEADER & YEAR TUTOR & PERSONAL TUTOR \\
\hline $\begin{array}{l}\text { - National and Internal Student Survey strategies } \\
\text { - Organise enrichment activities } \\
\text { - Secure funding, staffing and institutional approval }\end{array}$ & $\begin{array}{l}\text { - Student voice activities } \\
\text { - Co-ordinate extra-curricular activities }\end{array}$ & $\begin{array}{l}\text { - Maintain frequent contact with tutees } \\
\text { - Referrals to support services } \\
\text { - Pastoral support }\end{array}$ \\
\hline \multicolumn{3}{|c|}{ GRADUATE EXPERIENCE } \\
\hline PROGRAMME LEADER & YEAR TUTOR & PERSONAL TUTOR \\
\hline $\begin{array}{l}\text { - Foster external networks } \\
\text { - Assist in planning for graduation } \\
\text { - Liaise with professional and regulatory bodies }\end{array}$ & $\begin{array}{l}\text { - Liaise with placement team to ensure facilitated } \\
\text { placement and internship opportunities through } \\
\text { the year }\end{array}$ & $\begin{array}{l}\text { - Support with personal development planning } \\
\text { - Write references } \\
\text { - Facilitate and nurture personal growth }\end{array}$ \\
\hline
\end{tabular}

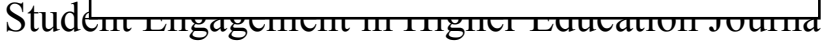

Vol 2, Issue 2, January 2019 


\section{References}

Atkinson, S. P. (2014). Rethinking personal tutoring systems: the need to build on a foundation of epistemological beliefs. London: BPP University.

Biddle, B. J. (2013) Role Theory: Expectations, Identities and Behaviours, London, Academic Press.

Bowden, J. L. (2013). "What's in a relationship?: Affective commitment, bonding and the tertiary first year experience - a student and faculty perspective", Asia Pacific Journal of Marketing and Logistics, 25(3), 428 - 451.

Brookfield, S. D. (1995). Becoming a Critically Reflective Teacher. SanFrancisco: Jossey-Bass.

Buultjens, M., \& Robinson, P. (2011). Enhancing aspects of the higher education student experience. Journal of Higher Education Policy and Management, 33(4), 337-346.

Constanti, P. \& Gibbs, P. (2004). Higher Education Teachers and Emotional Labour, International Journal of Educational Management, 18(4), 243-249.

Coventry University. (2015). Job Description. [Accessed 1st April 2017] http://www.coventry.ac.uk/Global/Coventry\%20University $\% 20$ Vancancy $\% 20$ Documents/JDREQ002841\%20Senior\%20Lecturer\%20in\%20Law\%200.6FT E.pdf

Dobinson-Harrington, A. (2006). Personal tutor encounters: understanding the experience. Nursing Standard. 20(50), 35-42.

Douglas, J. A., Douglas, A., McClelland, R. J., \& Davies, J. (2015).

Understanding student satisfaction and dissatisfaction: an interpretive study in the UK higher education context. Studies in Higher Education, 40(2), 329349.

Earwalker, J. (1992). Helping and Supporting Students. Buckingham: The Society for Research into Higher Education \& OU Press.

Faulkner, J., \& Crowhurst, M. (2015). "I was made to feel very discriminated against as an anglo-saxon" Grappling with pedagogies of change. Qualitative Research Journal, 15(2), 202-212.

Frank, G. (1997), "Is there life after categories? Reflexivity in qualitative research", Occupational Therapy Journal of Research, 17(2), 84-98.

Grant, A. (2006). Personal tutoring: A system in crisis? In: Thomas, L. and Hixenbaugh, P. (eds.) Personal Tutoring in Higher Education. Stoke on Trent: Trentham Books.

Hartwell, H. \& Farbrother, C. (2006). Enhancing the first year experience through personal tutoring. Personal Tutoring in Higher Education. Stoke on Trent: Trentham Books.

HEQC. (1996). Personal Tutoring and Academic Advice in Focus. London: Society for Research into Higher Education and Open University Press.

Hill, F. M. (1995). Managing service quality in higher education: the role of the student as primary consumer. Quality assurance in education, 3(3), 10-21.

Kilduff, A. (2014). Student life-First port of call at college: Make sure you make the most of the guidance and support your personal tutor has to offer, says Alison Kilduff. Nursing Standard, 29(8), 74-74.

Knight, P. \& Trowler, P. (2001). Departmental leadership in higher education. London: McGraw-Hill Education (UK). 
Krause, K. (2005). Serious thoughts about dropping out in first year: trends, patterns and implications for higher education. Studies in Learning, Evaluation, Innovation and Development, 2(3), 55-67

Krause, K-L. \& Coates, H. (2008). Students' engagement in first-year university. Assessment \& Evaluation in Higher Education, 33(5), 493-505.

Lancaster University. (2015). Job Description [Accessed 1st April 2017] http://hrjobs.lancs.ac.uk/Upload/vacancies/files/2435/A1128\%20jd\%20Senior\%20Le cturer.pdf

McCaig, C. (2016). The retreat from widening participation? The National Scholarship Programme and new access agreements in English higher education. Studies in Higher Education, 41(2), 215-230.

Milburn, P. C. (2010). The role of programme directors as academic leaders. Active learning in higher education, 11(2), 87-95.

Mitchell, R. (2015). 'If there is a job description I don't think I've read one': a case study of programme leadership in a UK pre-1992 university. Journal of Further and Higher Education, 39(5), 713-732.

Moustakas, C. 1994. Phenomenological research methods, Thousand Oaks, CA: Sage.

Murphy, M. \& Curtis, W. (2013). The micro-politics of micro-leadership: exploring the role of programme leader in English universities. Journal of Higher Education Policy and Management, 35(1), 34-44.

Ndebele, C. (2014). Using Evaluation as Action Research: Reflections on Teaching Practice Using Brookfield's Four Lenses Model. Anthropologist, 17(2), 533-541.

Nelson, K.J., Kift, S.M. \& Clarke, J.A. (2012), "A transition pedagogy for student engagement and first year learning, success and retention", in Solomonides, I., Reid, A. \& Petocz, P. (Eds), Engaging with Learning in Higher Education, Libri, Faringdon

Newton, A. and Smith, L. N. (1998). Practice placement supervision: the role of the personal tutor. Nurse Education Today, 18(6), 496-504.

Newton, J. (2002). Barriers to effective quality management and leadership: Case study of two academic departments. Higher education, 44(2), 185-212.

Owen, M. (2002). Sometimes you feel you're in niche time. Active Learning in Higher Education, 3(1), 7-23.

Palfreyman, D. \& Tapper, T. (2014). Reshaping the University: The Rise of the Regulated Market in Higher Education, Oxford, Oxford University Press

Palmer, M., O'Kane, P. \& Owens, M. (2009) Betwixt spaces: student accounts of turning point experiences in the first-year transition, Studies in Higher Education, 34(1), 37-54.

Palmer, S. (2006). Personal tutoring in the Faculty of Humanities, Management, Social and Applied Sciences [Accessed 31 ${ }^{\text {st }}$ January 2017]. www.heacademy.ac.uk.

Paterson, H. (1999). The changing role of the course leader within a higher education/further education context. Research in Post-Compulsory Education, 4(1), 97-116.

Perry, W.G. (1970). Forms of Intellectual and Ethical Development in the College Years. New York, NY: Holy, Rinehart and Winston.

Quinn, F. M. (2000). The principles and practice of nurse education. Nelson Thornes. 
Robertson, M. (2014). Analytics and Coaching for Success. ITNOW, 56(2), 4243.

Samah, N. A. (2013). Seeing with new eyes: Becoming a narrative inquirer in higher education practice. In S. Trahar (Ed.). Contextualising Narrative Inquiry: Developing Methodological Approaches for Local Contexts. London: Routledge. pp 89-107.

Sanders, P. (1982). "Phenomenology: A New Way of Viewing Organizational Research", Academy of Management Review, 7(3), 353-360.

Staddon, E. \& Standish, P. (2012). Improving the student experience. Journal of Philosophy of Education, 46(4), 631-648.

Strauss, A. \& Corbin, J. (1998), Basics of qualitative research: techniques and procedures for developing grounded theory, $2^{\text {nd }}$ ed., London: Sage.

Tait, A. (1998). Guidance and counselling in the Open University. In M. Crawford, R. Edwards \& L. Kidd (Eds.) Taking Issue: Debates in Guidance and Counselling in Learning, Abingdon: Open University/Routledge. 115127.

Temple, P., Callender, C., Grove, L. \& Kersh, N. (2014) Managing the student experience in a shifting higher education landscape. York: The Higher Education Academy.

Terenzini, P. T., Pascarella, E. T., \& Blimling, G. S. (1996). Students' out-ofclass experiences and their influence on learning and cognitive development: A literature review. Journal of college student development. 37(2), 149-162.

Thomas, L. (2006). Widening participation and the increased need for personal tutoring. In: Thomas, L. \& Hixenbaugh, P. (Eds.), Personal Tutoring in Higher Education. Stoke on Trent: Trentham Books, 21-31.

Thompson, L. J., Clark, G., Walker, M. \& Whyatt, J. D. (2013). 'It's just like an extra string to your bow': Exploring higher education students' perceptions and experiences of extracurricular activity and employability. Active Learning in Higher Education, 14(2), 135-147.

Vilkinas, T. \& Ladyshewsky R. (2012). "Leadership Behaviour and Effectiveness of Academic Program Directors in Australian Universities." Educational Management Administration \& Leadership, 40(1), 109-126.

Vinson, D., Nixon, S., Walsh, B., Walker, C., Mitchell, E. \& Zaitseva, E. (2010). Investigating the relationship between student engagement and transition. Active Learning in Higher Education, 11(2), 131-143.

Wheeler, S. \& Birtle, J. (1993). A Handbook for Personal Tutors. Bristol: Taylor and Francis Publishers.

Wilcox, P. Winn, S. \& Fyvie-Gauld, M. (2005). 'It was nothing to do with the university, it was just the people': the role of social support in the first year experience of higher education. Studies in Higher Education, 30(6), 707-722.

Willcoxson, L. Cotter, J. \& Joy, S. (2011), "Beyond the first year experience: the impact of attrition of student experiences throughout undergraduate degree studies in six universities", Studies in Higher Education, 36(3), 310-352.

Willmot, L. \& Lloyd, P. (2005). Improving the support and retention of students: a case study. [Accessed 19th May 2017]. www.heacademy.ac.uk/resources.asp?process=full record\&section=generic $\underline{\text { \&id }}$ 